\title{
CYTOTOXIC EFFECT OF Melia azedarch and Moringa Oleifera ON LIVER AND BREAST CANCER
}

\author{
Ahmed M.M. Helal", S.S. Elsaadany, R.A. Elmassry and H.T. Mansour \\ Agric. Biochem. Dept., Fac. Agric., Zagazig Univ., Egypt
}

Received: 27/03/2017 ; Accepted: 7/ 5 /2017

\begin{abstract}
Cancer is a big health problem with high morbidity and mortality and possess both economic and psychological challenges. The aim of the present study is to evaluate methanolic $70 \%$ melia azedarch and moringa extracts for their anticancer activities using two cancer cell lines: hepatocellular carcinoma cell line (HePG2) and breast carcinoma cells lines (MCF7). The results showed that Melia azedarch methanolic 70\% extract exhibited a pronounced cytotoxic effect and was found to possess a very potent inhibitory activities against hepatocellular carcinoma cell line (HePG2) and breast carcinoma cells lines (MCF7). In vitro studies of methanolic 70\% of Moringa olefiera extract showed no activity on both cancer cell lines hepatocellular carcinoma cell line (HePG2) and breast car cinoma cells line (MCF 7).
\end{abstract}

Key words: Melia azedarch, Moringa oleifera, antibacterial, antioxidant, antitumor.

\section{INTRODUCTION}

Cancer is a big health problem with high morbidity and mortality and possess both economic and psychological challenges (Dossus and Kaaks, 2008). Cancers result from cells growing in uncontrolled and abnormal fashions, and the resulting tumors are classified as either benign or malignant. While benign tumors do not invade the surrounding tissue, malignant tumors aggressively invade surrounding tissues, altering the surrounding tissue's natural function. When malignant tumor cells spread to the lymph and circulatory systems, the metastatic cascade begins, spreading cancer cells throughout the body. Control of cancer may be accomplished by a variety of means, including suppressing, blocking, and transforming agents. The use of suppression agents prevent the formation of new cancers from procarcinogensis, while blocking agents prevent carcinogenic compounds from reaching critical initiation sites and transformation agents act to facilitate the metabolism of carcinogenic components into less toxic materials or to prevent the biological actions of the carcinogen. Other methods for controlling cancer involve blocking metastatic cascades through inhibiting cancer cell invasion into surrounding tissues or by inhibiting cancer cell mobility in circulatory systems (Wattenberg, 1992)

It is known that different cell lines might exhibit different sensitivities towards an antiproliferative compound, so the use of more than one cell line is therefor reconsidered necessary in the detection of anti proliferative compounds. Breast cancer starts when cells in the breast begin to grow out of control. The cells usually form a tumor that can often be seen on an x-ray or felt as a lump. The tumor is malignant (cancerous) if the cells can grow into (invade) surrounding tissues or spread (metastasize) to distant areas of the body. Breast cancer occurs almost entirely in women, but men can get it, too. Cells in nearly any part of the body can become cancer, and can spread to other areas of the body breast cancers can start from different parts of the breast. Most breast cancers begin in the ducts that carry milk to the nipple (ductal cancers). Some start in the glands that make breast milk (lobular cancers). There

\footnotetext{
* Corresponding author: Tel. : +201142865643

E-mail address: ahmedhelal@yahoo.com
} 
are also other types of breast cancer that are less common. A small number of cancers start in other tissues in the breast. These cancers are called sarcomas and lymphomas and are not really thought of as breast cancers. Although many types of breast cancer can cause a lump in the breast, not all do. There are other symptoms of breast cancer you should watchout for and report to a health care provider. It's also important to understand that most breast lumps are not cancer, they are benign. Benign breast tumors are abnormal growths, but they do not spread outside of the breast and they are not life threatening, but some benign breast lumps can increase a woman's getting breast cancer. Any breast lump or change needs to be checked by a health care provider to determine whether it is benign or cancer, and whether, it might impact your future cancer risk (Weber, 2008). Liver cancer is that begins in the liver. About $80 \%$ of primary liver cancer is hepatocellular carcinoma (HCC). Other subtypes of primary liver cancer include bile duct cancer and angiosarcoma, acancer of the blood vessels in the liver.

The aim of the present study was to evaluate the use of methanolic 70\% melia azedarch and moringa oleifera extracts for their anticancer activity using two cancer cell lines: hepatocellular carcinoma cell line (HePG2) and breast carcinoma cells lines (MCF7).

\section{MATERIALS AND METHODS}

The leaves of Moringa oleifera were obtained from Research Center Department of Medical and Aromatic Plants, Giza, Egypt in 2016. The seeds of Melia azedarch were collected from Faculty of Agriculture Zagazig University. Zagazig, Egypt in 2016.

\section{SRB Assay}

Potential cytotoxicity of the methanolic $70 \%$ extract of melia azedarch was tested for breast cancer carcinoma cell line (MCF7) and hepatocellular carcinoma cell line (HePG2) using the method of Skehan and Storeng (1990) as follows: Cells (MCF7) and (HePG2) were plated in 96-multiwell plate $\left(10^{4}\right.$ cells/well) for 24 hours before the treatment with the extract to allow the attachment of cells to the wall of the plate. Different concentrations of the tested extracts were added to the cells monolayer, 6 replicates wells were prepared for dose.

- Monolayer cells were incubated with the extracts for 48 hours at $37^{\circ} \mathrm{C}$ and in atmosphere of $5 \% \mathrm{CO}_{2}$.

- After 48 hours, cells were fixed, washed and stained with sulfo-Rhodamine-B stain. Excess stain was washed with acetic acid and the attached stain was recovered with Tris EDTA buffer.

- Color intensity was measured in an ELISA reader.

- The relation between surviving fraction and extract concentration after the specified compound.

- $\mathrm{IC}_{50}$ of this extract against both cell lines were calculated using these survival curves.

\section{RESULTS AND DISCUSSION}

\section{Cytotoxic Effect of Melia azedarch}

The result showed that Melia azedarch methanolic $70 \%$ extract exhibited a pronounced cytotoxic effect and was found to possess a very potent inhibitory activities against hepatocellular carcinoma, cell line (HePG2) and breast carcinoma cells, lines (MCF7). $\mathrm{IC}_{50}$ of this extract against (HePG2) and (MCF7) cell line decreases reactive oxygen species. Chlorogenic acid induces endogenous antioxidant until its activity increases. It is known for its function as an exogen antioxidant to prevent cell damage and inhibits cancer cell growth by binding with free radical agents. The chlorogenic acid has a role to inhibit Cell Lines (HepG2) growth through oxidation-reduction reaction by trapping free radical agents that eventually decreases reactive oxygen species. An antioxidant is a molecule that can slow or prevent oxidation reactions with other chemicals the action mechanism of chlorogenic acid as chemopreventive is to inhibit free radical called antioxidant. Oxidation is a chemical reaction redox move electrons from a substance to an oxidizing agent. The oxidation reaction, can cause the onset of free radicals, may give rise to a dangerous chain reaction. Antioxidants may terminate these chain reactions by removing radical substance, and inhibit other oxidation reactions by oxidizing the substances 
themselves. Therefore, most of the antioxidant substances called reducing agents such as thiols or phenols. Antioxidants can be produced in the body or obtained from the diet (Paynter et al., 2006).

Several mechanisms have been postulated for the tumor growth-inhibitory effects of flavonoids, including, but not limited to, the inhibition of NF-kB signaling pathway (Sarkar et al.., 2009). NF-kB plays an essential role during inflammation immune responses as well as in other physiological functions such as cell growth, apoptosis (Park et al., 2013). Recent studies have shown that inactivation of the NF$\mathrm{kB}$ in the hepatic compartment inhibits liver tumor formation through induction of cell death inhibition of compensatory proliferation. Furthermore, mounting evidence has illustrated a major role of NF-kB in inducible chemoresistance of HCCs (Wang et al., 2007).

Flavonoid induction of liver enzymes may also ultimately affect the metabolism of endogenous substrates, e.g. steroid hormones (Dai et al., 1997), and thus indirectly influence a great number of biological processes in humans.

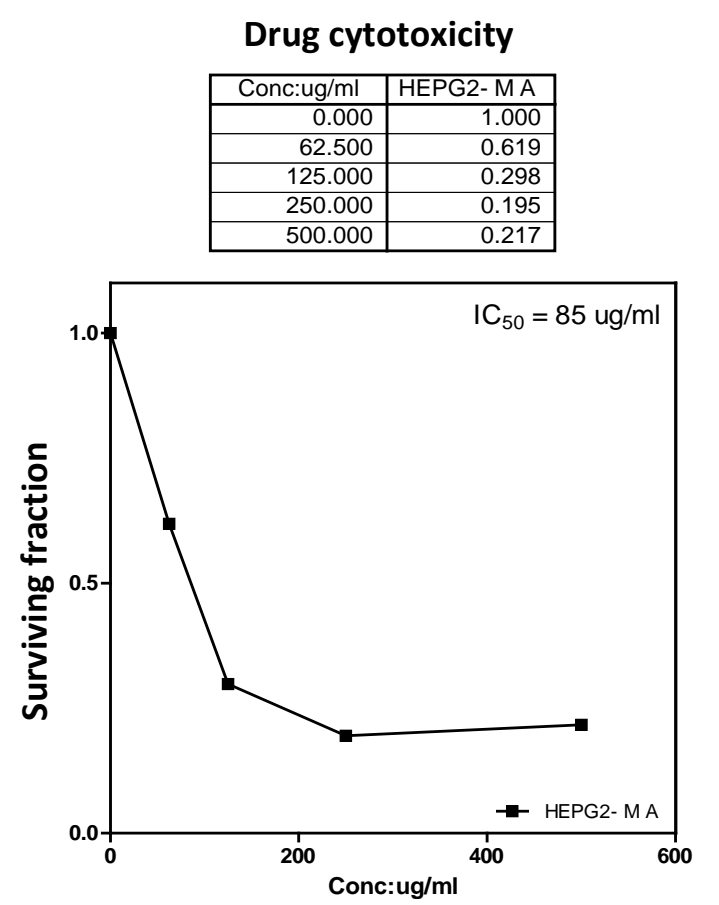

Fig. 1. Cytotoxicity effect of Melia azedarch methanolic extract on hepatocellular carcinoma cell line
Typically, inducers of liver enzymes can be divided into 2 classes: 1) bifunctional inducers that induce phase I enzymes, e.g. cytochrome P450 isozymes, involved in the synthesis of metabolites responsible for the activation of genes encoding phase II enzymes, and 2) monofunctional inducers that induce phase II enzymes directly without influencing the levels of phase I enzymes (Yannai et al., 1998). While many flavonoids have been reported to be bifunctional inducers (Talalay et al., 1988), flavones and flavonols were recently shown to be strong inducers of the phase II enzyme quinone reductase in wild-type murine hepatoma cells. These effects were also determined in a similar cell line insensitive to bifunctional induction of phase II enzymes. In these cell lines kaempferol was a monofunctional inducer of phase II enzymes, whereas kaempferol-4'methyl ether was a strict bifunctional inducer. Quercetin and quercetin-4'-Oglucoside were monofunctional inducers, while tamaraxetin and rhamnetin acted as bifunctional inducers. These results indicated that methoxylation at the $\mathrm{C}^{\prime}$ ' position tightly controlled the induction by these flavonoids according to (John and Najla, 2002).

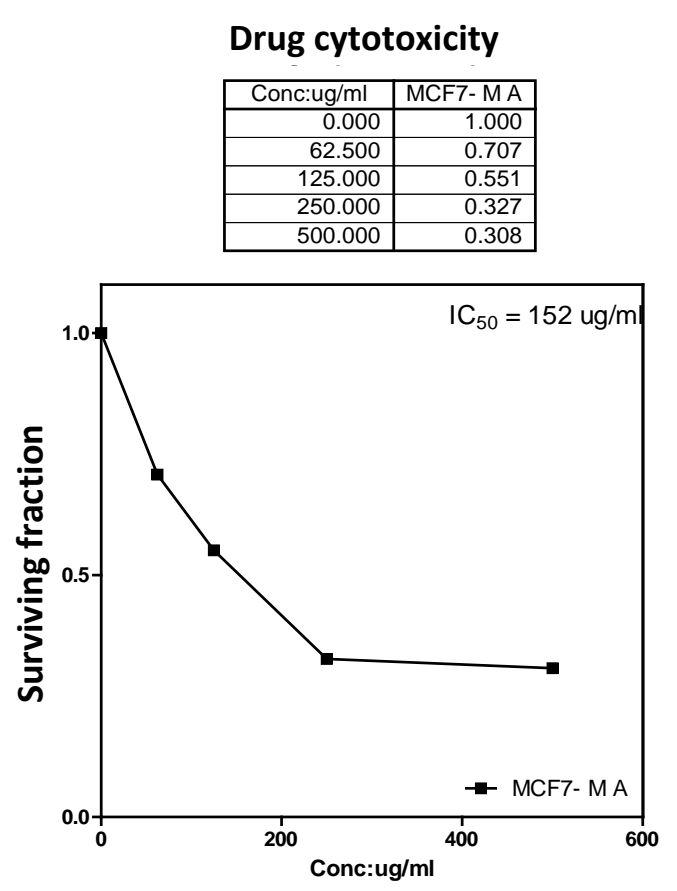

Fig. 2. Cytotoxicity effect of Melia azedarch methanolic extract on breast carcinoma cell line 
Cytotoxic Effect of Moringa olefiera on Human Cell Line (HePG2 and MCF7)

It is known that different cell lines might exhibit different sensitivities towards anti proliferative compound, so the use of more than one cell line is there fore considered necessary in the detection of anti proliferative compounds. In vitro studies of methanolic $70 \%$ of Moringa olefiera extract showed no activity on both cancer cell lines hepatocellular carcinoma cell line (HePG2) and breast carcinoma cells lines (MCF7).

\section{REFERENCES}

Dai, R., K.A. Jacobson, R.C. Robinson and F.K. Friedman (1997). Differential effects of flavonoids on testosterone-metabolizing cytochrome.

Dossus, L. and R. Kaaks (2008). Nutrion, metabolic factors and cancer risk, Best Pract. Res. Clini. Endocrinolo. Metabolism, 22 (4): 551-571.

John, A.M. and Najla, G. (2002). Antiproliferative Activities of Citrus Flavonoids against Six Human Cancer Cell Lines, J. Agric. Food Chem., 50:5837-5843.

Park, E., S.M. Lee, J.E. Lee and J.H. Kim (2013). Anti-inflammatory activity of mulberry leaf extract through inhibition of NF-kB. J. Functional Foods, 5 (1):178-186.
Paynter, P., Y. Hsin-Chieh, V. Sari, I.S. Maria, H. Gerardo, R.F. Aaron and L. Frederick (2006). Ame. J. Epidemiol., 164 (11): 1075-1084.

Sarkar, F.H., Y. Li, Z. Wang and D. Kong (2009). Cellular signaling perturbation by natural products. Cell Signal, 21 (11): 15411547.

Skehan, P. and R. Storeng (1990). New colorimetric cytotoxicity assay for anticancer drug screening. J. Nat. Cancer Inst., 82 (13): 1107-1112.

Talalay, P., M.J. De Long and H.J. Prochaska (1988). Identification of a common chemical signal regulating the induction of enzymes that protect against chemical carcinogenesis. Proc. Natl. Acad. Sci. (USA), 85:8261- 8265.

Wang, P.M., H.S. Chen, W.Y. Wang, Y.S. Liang and Y. Su (2007). Matrix metalloproteinase-7 increases resistance to Fas-mediated apoptosis and is a poor prognostic factor of patients with colorectal carcinoma. Carcinog., 27 (5): 1113-1120.

Wattenberg, L.W. (1992). Inhibition of carcinogenesis by minor dietary constituents. Cancer Res., 52 (7): 2085 - 2097.

Weber, B.L. (2008). Cancer of the Breast in : Abel off MD Armitage Jo, L : ether As, and eds.clinical on colocy. $4^{\text {th }}$ Ed. Philadelphia, pa : Elservier; 1875 - 1943.

Yannai, S., A.J. Day, G. Williamson and Rhodes, M.J.C. (1998). Advances in enzyme Regulation, Food Chem. Toxicol., 36:623-630.

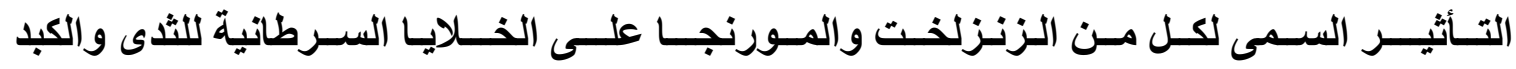

$$
\begin{aligned}
& \text { أحمد محمد محمد هلال - السيد سليمان السعدنى - رجب عبد الفتاح المصري- حفناوى طه منصور } \\
& \text { قسم الكيمياء الحيوية الزر اعية ـ كلية الزر اعة ـ جامعة الزقازيق ـ مصر }
\end{aligned}
$$

